\title{
A CONTACT ZONE BETWEEN COASTAL AND INTERIOR FOX SPARROWS IN SOUTH-CENTRAL ALASKA *
}

\author{
LUCAS H. DeCICCO, Department of Ecology and Evolutionary Biology and \\ Biodiversity Institute, University of Kansas, Lawrence, Kansas 66045; \\ lhdecicco@gmail.com
}

ABSTRACT: I report observations, supported by museum voucher specimens, photographs, and audio recordings, from an area of breeding contact between two divergent groups of subspecies of the Fox Sparrow (Passerella iliaca) in upper Cook Inlet, south-central Alaska. In this area, covering $\sim 50 \mathrm{~km}^{2}$, the interior iliaca group comes in contact with the Pacific coast unalaschcensis group in lowland mixed boreal forest. Phenotypically pure $P$. i. zaboria and $P$. i. sinuosa (subspecies representing the iliaca and unalaschcensis groups, respectively) occur in approximately equal abundances and outnumber intermediate phenotypes. These subspecies co-occur on a fine scale, males of zaboria and sinuosa often holding adjacent territories. I conclude that some form of pre- or post-zygotic isolating mechanism between these two subspecies-groups is hindering free interbreeding.

Areas of secondary contact between closely related taxa form ideal scenarios for studying myriad aspects of compatibility, isolating mechanisms, and speciation (e.g., Harrison 1993). Although intermediate phenotypes indicating regions of hybridization have been recognized since early in the biological exploration of North America (e.g., Audubon in 1843, in Short 1965), focused research on hybrid zones in North America started in earnest with descriptions of clines in plumage variation (e.g., Short 1965, Rising 1983). Subsequently, research on hybrid zones has expanded into more detailed studies of the associations among plumage, vocalizations, and genomic clines (e.g., Dixon 1989, Mettler and Spellman 2009, Manthey and Robbins 2016, Toews et al. 2016, Irwin et al. 2018, Billerman et al. 2019, Oswald et al. 2019). Levels of compatibility and hybridization across these secondary contact zones vary with degree of divergence and breeding isolation between contacting taxa and cover a continuum from free interbreeding with wide clines of intermediate phenotypes, as in the flickers (e.g., Short 1965), to very narrow contact or overlap zones, as in the scrub-jays (e.g., Delaney et al. 2008). The latter scenario may result in an overlap zone with a mix of phenotypes at any single site including apparently pure parental and intermediate phenotypes.

Although some contact zones are very well studied (e.g., Sibley and Short 1964, Rising 1970, Jacobsen and Omland 2012, Baldassarre et al. 2014, Walsh et al. 2020), others remain barely described. Despite the attention contact zones have received from evolutionary and genomic research, there is still a

\footnotetext{
* I dedicate this paper to the memory of Leonard J. Peyton (1924-2010), a determined field ornithologist and a pioneer in audio recording the vocalizations of Alaska's birds. He harbored a keen interest in the variation of the Fox Sparrow's song, particularly in the contact area between subspecies groups in south-central Alaska, including upper Cook Inlet. Leonard's audio recordings were deposited at the University of Alaska Museum's Film Center, documenting his interest in the subject. I hope he would be proud to see a subject so close to his heart come into print.
} 
need for descriptive ornithological work on under-studied areas of contact. Here I take the opportunity to describe a poorly known area of contact between two subspecies-groups of the Fox Sparrow (Passerella iliaca) to provide a foundation for future research.

The Fox Sparrow is "variable to an extreme degree" (Swarth 1920) and comprises 19 described subspecies, ranking it among the species with the most complex geographic variation in North America. These 19 subspecies are parsed into three (Swarth 1920) or four (Zink and Weckstein 2003) groups and have also been considered to represent four species (e.g., Gill et al. 2020), though the contact zones remain poorly studied. Two subspecies-groups occur in Alaska, the iliaca group, which nests across boreal North America from western Alaska to maritime Canada, and the unalaschcensis group, which nests along the Pacific coast from southern British Columbia to the eastern Aleutian Islands (Gibson and Withrow 2015). Within Alaska the iliaca group is represented by subspecies zaboria and the unalaschcensis group by the subspecies unalaschcensis, insularis, sinuosa, annectens, townsendi, and chilcatensis (Gibson and Withrow 2015).

The iliaca and unalaschcensis groups come into breeding contact in limited areas where interior and coastal faunas mix along the Pacific coast. From intermediate specimens collected in the winter range, Swarth (1920) suggested that these groups interbreed, and Zink (1994) found evidence of genetic mixing between these groups near Telegraph Creek in British Columbia. Williamson and Peyton (1962) discussed an area of confusing mixing of three subspecies on the Alaska Peninsula, where they suggested unalaschcensis, sinuosa, and zaboria all came into breeding contact. Of interest, Williamson and Peyton (1962) noted that intergrades between zaboria and unalaschcensis or sinuosa were rare and that this zone of contact was narrow, suggesting recent contact of well-differentiated forms. If contact between zaboria and chilcatensis or townsendi occurs in major river drainages along the Pacific coast of southeastern Alaska, such contact has not been noted in the literature. In south-central Alaska there are three known regions of contact between sinuosa and zaboria: the Copper River valley, the Tsina/ Tiekel River drainage inland of Valdez, and the Cook Inlet area (Williamson and Peyton 1962, Gibson and Withrow 2015; University of Alaska Museum [UAM] specimens). Regarding the Cook Inlet contact area near Anchorage, Williamson and Peyton (1962:63) were the first to make mention of this apparently unknown contact area and noted that "hybrids are rare, even in areas where pairs of both races nest in proximity." These areas are known for drawing interior taxa to otherwise coastal faunal regions, and vice versa (Gibson and Withrow 2015).

Here I detail observations from a contact area in upper Cook Inlet made opportunistically over four years, assess the breeding interaction between these two subspecies, and describe their variation in plumage and voice. I mean this publication to provide preliminary documentation of the poorly understood contact area in upper Cook Inlet in hopes that future research may build on this groundwork. 


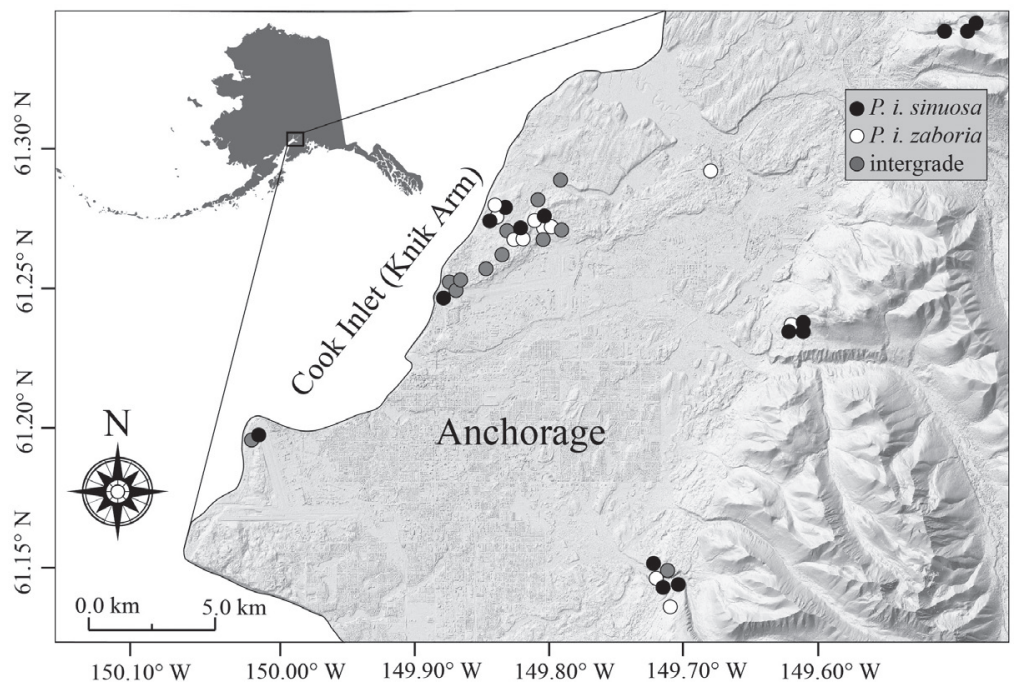

Figure 1. Map of the Anchorage area and foothills of the Chugach Mountains with sites of specimens of Passerella iliaca indicated by circles. Black fill, the coastal subspecies sinuosa; white fill, the interior subspecies zaboria; gray fill, intermediate specimens. Note the thorough spatial mixing of phenotypes in this area.

\section{METHODS}

Over four years (2013-2016), I made observations, collected specimens (deposited at the UAM, in Fairbanks), and made audio recordings (deposited at the Macaulay Library, Cornell Lab of Ornithology [ML]) of breeding Fox Sparrows around upper Cook Inlet, south-central Alaska. Most of the observations were in lowland mature mixed boreal forest $\sim 10 \mathrm{~km}$ northeast of Anchorage, an area measuring $\sim 5 \times 10 \mathrm{~km}$ and ranging in elevation from $0 \mathrm{~m}$ to $100 \mathrm{~m}$ above sea level $\left(61.282^{\circ} \mathrm{N}, 149.800^{\circ} \mathrm{W}\right.$; Figure 1$)$. These mixed boreal forests are characterized by aspen (Populus tremuloides), balsam poplars (Populus balsamifera), and paper birch (Betula papyrifera) interspersed with stands of white spruce (Picea glauca) and patches of alder (Alnus sp.) in natural openings or along forest edges. I also made observations in the foothills of the Chugach Mountains at elevations up to $\sim 600 \mathrm{~m}$ (Figure 1). I took note of the habitat associations of territorial birds and any information I could obtain on pairing. All my observations come from late April through June (spring arrival in this area is typically mid- to late April), and most information is from territorial males. I lacked the time required to assess levels of assortative mating and the frequency of mixed pairings by identifying both individuals of a pair. Therefore, it was unusual for me to be able to observe, photograph, or collect a paired female. As my goal was to document this area of contact, my sampling focused on providing representative examples of the phenotypes and does not represent the abundance of each phenotype-intergrades are over-represented in my specimen series with respect to their observed abundance in the field. 


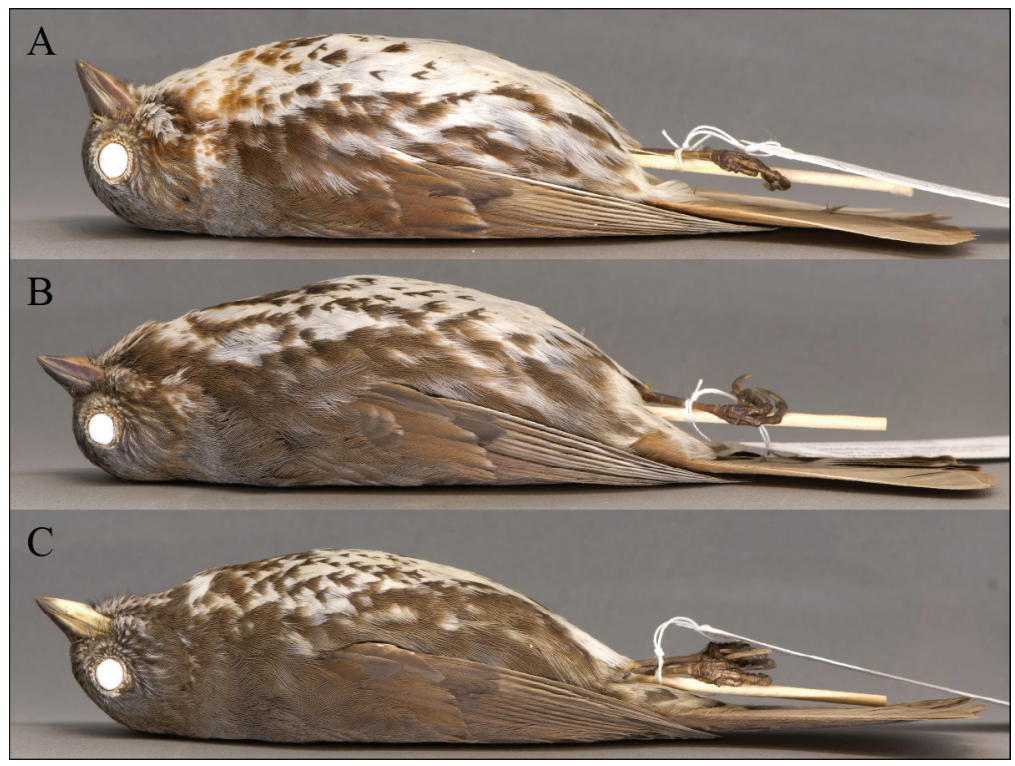

Figure 2. Side view of Fox Sparrow specimens from the area of contact of Passerella iliaca zaboria and sinuosa around upper Cook Inlet, south-central Alaska. (A, UAM 34095) Subspecies zaboria, representing the interior iliaca subspecies-group; (B, UAM 41232) individual of intermediate plumage assumed to be an intergrade; and (C, UAM 36901) subspecies sinuosa, representing the coastal unalaschcensis subspecies-group. Note differences in patterning and coloration of the face, flanks, and greater wing coverts.

Photos by Lucas DeCicco

\section{RESULTS}

Between 2013 and 2016, I collected 39 Fox Sparrow specimens, 15 of which have associated audio recordings (Table 1). Twenty-three of these specimens came from the $5 \times 10-\mathrm{km}$ area of mixed lowland boreal forest described above and represent the mix of phenotypes at a single site in a contact area between the iliaca and unalaschcensis subspecies-groups. Of the 45 nesting-season specimens available from upper Cook Inlet (39 collected from 2013 to 2016 and six collected in 1969), I identified 12 as zaboria, 24 as sinuosa, and nine as showing intermediate characteristics so presumably representing intergrades. Of the 23 from the $5 \times 10-\mathrm{km}$ area of lowland mixed boreal forest, I identified eight as zaboria, eight as sinuosa, and seven as intergrades. Again, this is not an appropriate assessment of the abundance of intergrades because I targeted those phenotypes to provide adequate representation in the specimen series.

On the basis of these specimens and observations I conclude that phenotypically pure examples of zaboria and sinuosa occur at approximately equal abundances in this area, they freely intermix spatially, and phenotypically intermediate individuals occur but are less numerous than parental phenotypes (Figure 1, Table 1). At this location, it is not uncommon for males of the two taxa to hold neighboring territories, but these subspecies differ in habitat 
TABLE 1 Specimens of the Fox Sparrow from the Anchorage Area, South-Central Alaska

\begin{tabular}{|c|c|c|c|c|c|c|c|}
\hline Specimen $^{a}$ & Sex & Date & Locality & Latitude & Longitude & Elevation (m) & Audio $^{b}$ \\
\hline \multicolumn{8}{|l|}{ P. i. sinuosa } \\
\hline 4337 & 0 & 16 June 1969 & Point Woronzof & 61.200 & -150.022 & 28 & - \\
\hline 4342 & $\hat{0}$ & 16 June 1969 & Point Woronzof & 1.200 & -150.022 & 28 & - \\
\hline 4350 & 0 & 16 June 1969 & Point Woronzof & 1.200 & -150.022 & 28 & - \\
\hline 4357 & $\hat{0}$ & 16 June 1969 & Point Woronzof & 61.200 & -150.022 & 28 & - \\
\hline 4359 & $\hat{0}$ & 16 June 1969 & Point Woronzof & 61.200 & -150.022 & 28 & - \\
\hline 34099 & $\hat{0}$ & 26 May 2013 & upper Carol Cr. & 61.342 & -149.506 & 537 & 118745 \\
\hline 34100 & 0 & 26 May 2013 & upper Carol Cr. & 1.342 & -149.489 & 745 & - \\
\hline 34101 & $\delta$ & 27 May 2013 & S Fork Campbell Cr. & 61.144 & -149.704 & 348 & 118751 \\
\hline 34102 & $\hat{0}$ & 1 June 2013 & Arctic Valley Rd. & 61.235 & -149.612 & 350 & 118759 \\
\hline 36899 & $\hat{0}$ & 17 June 2014 & upper Campbell Cr. & 61.147 & -149.713 & 274 & - \\
\hline 36900 & $\hat{0}$ & 17 June 2014 & upper Campbell Cr. & 61.150 & -149.714 & 273 & - \\
\hline 36901 & 0 & 18 May 2014 & upper Campbell Cr. & 61.147 & -149.713 & 274 & - \\
\hline 38224 & $\hat{\sigma}$ & 19 May 2015 & Triangle Lake & 61.272 & -149.815 & 107 & - \\
\hline 38225 & $\hat{\sigma}$ & 24 May 2015 & Ship Creek Valley & 1.237 & -149.610 & 400 & 516992 \\
\hline 38226 & $\delta$ & 241 & Ship & 6 & 1 & 90 & - \\
\hline 38227 & $\hat{0}$ & 24 May 2015 & Ship Creek Valley & 1.237 & -1 & 615 & 516993 \\
\hline 38228 & 0 & 23 May 2015 & 11 Track & 1.147 & -14 & 285 & - \\
\hline 38230 & $\hat{0}$ & 19 May 2015 & Triangle Lake & 1.272 & -149.794 & 89 & - \\
\hline 40393 & 0 & 4 June 2016 & W end Dena'ina Rd. & 61.247 & -149.878 & 41 & 56804531 \\
\hline 40394 & $\hat{0}$ & 23 May 2015 & Campbell Track & 61.147 & -149.713 & 273 & - \\
\hline 40395 & $\hat{\sigma}$ & 15 May 2016 & Green Lake & 61.281 & -149.840 & 44 & - \\
\hline 40397 & $\hat{\sigma}$ & 5 June 2016 & W end Dena'ina Rd. & 1.248 & -149.869 & 60 & - \\
\hline 40398 & 우 & 15 May 2016 & Gre & 1.281 & -1 & 44 & - \\
\hline 41230 & 0 & 27 May 2017 & Fish Lake & 276 & & 08 & - \\
\hline \multicolumn{8}{|l|}{ P. i. zaboria } \\
\hline 34095 & $\hat{0}$ & 7 Jun & ke & 1.272 & -149.821 & 62 & 118767 \\
\hline 34096 & 0 & 27 May 2013 & S Fork Can & 1.136 & 10 & 368 & 118748 \\
\hline 34097 & 0 & 1 June 2013 & Arctic Valley Rd. & 61.237 & -14 & 304 & 118757 \\
\hline 36902 & $\hat{0}$ & 17 June 2014 & upper Campbell Cr. & 1.147 & -14 & 244 & - \\
\hline 40402 & $\hat{\sigma}$ & 20 May 2015 & Sixmile Lake & 90 & 93 & 37 & 516708 \\
\hline 40403 & $\hat{0}$ & 29 May 2016 & e Lake & 72 & 98 & 90 & 64923281 \\
\hline 40404 & $\hat{0}$ & 13 May 2015 & Lake & 81 & 338 & 32 & 516681 \\
\hline 40405 & $\hat{0}$ & 28 May 2016 & Triangle Lake & 1.272 & -149.801 & 101 & - \\
\hline 40406 & $\hat{0}$ & 15 May 2016 & Green Lake & 61.280 & -149.840 & 35 & - \\
\hline 40407 & $\hat{0}$ & 29 May 2016 & Fish Lake & 61.269 & -149.817 & 94 & 64923911 \\
\hline 40408 & $\hat{0}$ & 14 May 2016 & Otter Lake & 61.292 & -149.680 & 49 & - \\
\hline 41233 & $\hat{0}^{\lambda}$ & 27 May 2017 & Fish Lake & 61.275 & -149.809 & 103 & - \\
\hline \multicolumn{8}{|c|}{$\times \operatorname{sinuosa}$} \\
\hline 4360 & $\hat{0}$ & 16 June 1969 & Point Wor & 200 & -15 & 28 & - \\
\hline 34098 & $\hat{0}$ & 5 June 2013 & Hillberg Lake & 61.272 & -149.822 & 56 & 118764 \\
\hline 36903 & $\hat{0}$ & 18 May 2014 & Upper Campbell Cr. & 61.149 & -149.712 & 274 & - \\
\hline 38229 & 0 & 13 May 2015 & Sixmile Lake & 61.281 & -149.807 & 65 & 516680 \\
\hline 40399 & 0 & 4 June 2016 & W end Dena'ina Rd. & 61.247 & -149.876 & 41 & - \\
\hline 40400 & 0 & 29 May 2016 & Fish Lake & 61.268 & -149.805 & 93 & - \\
\hline 40401 & 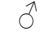 & 15 May 2016 & Triangle Lake & 61.261 & -149.835 & 93 & - \\
\hline 41231 & $\hat{0}$ & 27 May 2017 & W end Dena'ina Rd. & 61.248 & -149.874 & 44 & - \\
\hline 41232 & $\hat{\sigma}$ & 10 June 2017 & $\begin{array}{l}\text { Dena'ina Rd. \& } \\
\text { Fairchild Ave. }\end{array}$ & 61.257 & -149.847 & 75 & - \\
\hline
\end{tabular}

${ }^{a}$ All specimens archived at the University of Alaska Museum (UAM).

${ }^{b}$ All recordings archived at the Macaulay Library (ML), Cornell Lab of Ornithology. 
preferences, and their songs are recognizably different in the field. Due in part to this difference in habitat preference, there is also an elevational gradient, with sinuosa being more numerous at higher elevations where alder thickets, its preferred habitat, dominate over mixed boreal forest. Only in mixed boreal forest with natural openings with alder thickets did I find thorough spatial mixing of these subspecies.

\section{Phenotype Descriptions and Assessment}

The coastal unalaschcensis group differs from the interior iliaca group in many plumage aspects (Figures 2 and 3). In the iliaca group, the facial plumage is much more patterned with rusty-red auriculars contrasting with a gray crown and nape and a pale malar (Figure 2a). In sinuosa, the face is plain gray-brown with pale speckling in the lores and distal portion of the malar (Figure 2c). Individuals of subspecies sinuosa occurring near Anchorage show slight patterning with diffuse warmer brown plumage along the edge of the auriculars and upper nape into the crown (Figure 2c). The pattern of the mantle differs clearly, with zaboria showing a strongly patterned mantle with pale brownish gray contrasting with rich red-brown stripes (Figure 3a), sinuosa showing a uniform dark brown mantle (Figure 3c). Following these general patterns, the colors of the tail and upper tail coverts also differ, the tail being a rich rufous contrasting with the rump and back in zaboria (Figure 3a), while sinuosa has a dark chestnut tail and upper tail coverts barely contrasting with the upper rump and mantle (Figure 3c). Flank and breast patterning also differ: in zaboria the chevrons are rufous or chestnut-colored (Figure 2a), in sinuosa brown and denser (Figure 2c). The wing pattern, due primarily to the coloration and patterning of the wing coverts, differs with zaboria showing rufous-brown greater and median coverts with pale terminal spots that form a double wing bar (Figure 2a), sinuosa showing uniformly brown wing coverts (Figure 2c). Specimens I identified as intergrades were intermediate in these plumage characteristics (Figures $2 \mathrm{~b}$ and $3 \mathrm{~b}$ ). My identifications in the field and of the specimens were based primarily on these characteristics, with specimens also being compared to those from areas that should not show influence from other subspecies.

Intergrades between zaboria and sinuosa were intermediate, showing a diffusely striped mantle, faint facial pattern with a paler auricular triangle, flanks with streaks intermediate between the light streaks of zaboria and the heavy streaks of sinuosa, and a faint set of wing bars. In the field, these intermediate individuals might appear to be sinuosa, as their overall appearance was darker than zaboria, but the more subtle intermediate characteristics listed above clearly separate them from phenotypically pure sinuosa. It is worth noting that these phenotypes may not be representative of true levels of intergradation, as may be assessed by molecular techniques. For example, Zink (1994) found mtDNA haplotypes of the unalaschcensis group in individuals that appeared to be pure iliaca group on the basis of plumage. Thus introgression is likely greater than may be assessed from the phenotype alone. 


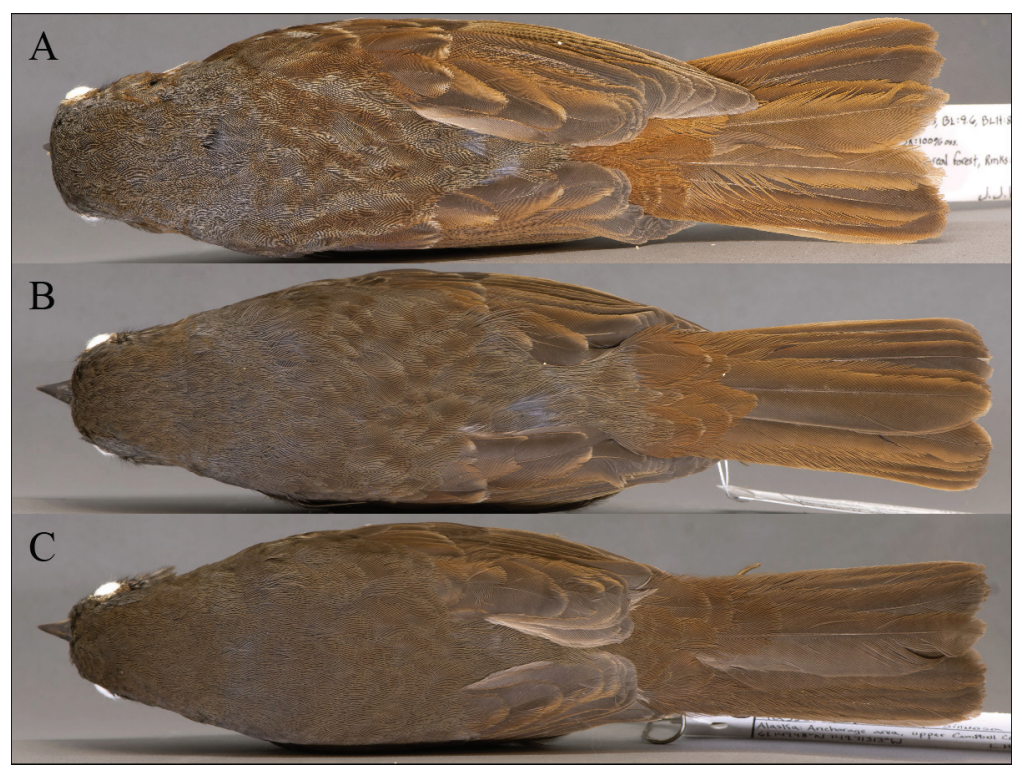

FIGURE 3. Dorsal view of Fox Sparrow specimens from the area of contact of Passerella iliaca zaboria and sinuosa around upper Cook Inlet, south-central Alaska. (A, UAM 34095) Subspecies zaboria, representing the interior iliaca subspecies-group; (B, UAM 41232) individual of intermediate plumage assumed to be an intergrade; and (C, UAM 36901) Subspecies sinuosa, representing the coastal unalaschcensis subspecies-group. Note the differences in mantle patterning and coloration and coloration and in contrast of the lower back, rump, and tail plumage.

Photos by Lucas DeCicco

\section{Habitat Association}

These two subspecies also differed in habitat association, with zaboria preferring deciduous boreal forest dominated by paper birch and aspen and sinuosa preferring thickets of alder that occurs as a successional or edge species. Within the area of mixed lowland boreal forest near Anchorage (elevation 0 to $\sim 100 \mathrm{~m}$ ), there are ample disturbed areas or natural openings where alders persist, constituting a natural mosaic of mature deciduous boreal forest and alder thickets (Figure 4). This intermixing of habitats facilitates close association of these two subspecies. A similar mosaic of habitat occurs at middle elevations ( 200-400 m) along the foothills of the Chugach Mountains, where I also found both sinuosa and zaboria co-occurring. Above $\sim 400$ $\mathrm{m}$ elevation in the Chugach Mountains, however, the habitat changes into subalpine meadows and alder thickets. At this higher elevation I was able to find examples of sinuosa only. Although the mosaic of habitat at the lowland site on which I focused is partially a result of anthropogenic disturbance, this same mosaic of habitat occurs naturally both at middle elevations and in lowland areas. 

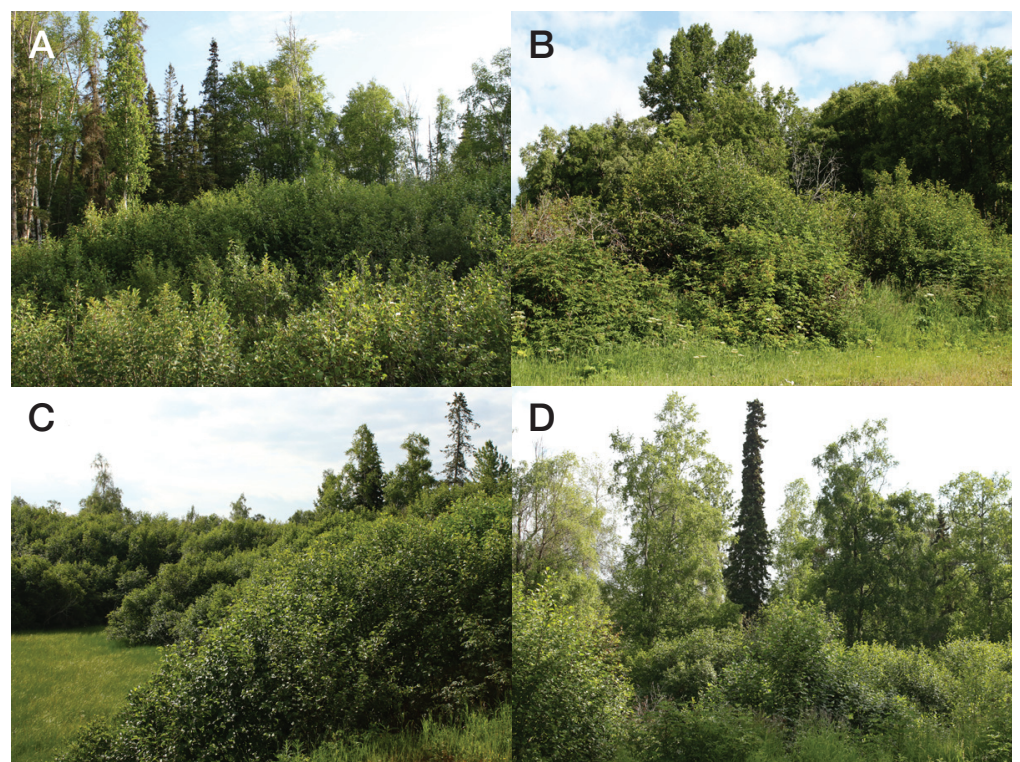

FiguRE 4. Examples of the mosaic of mixed boreal forest and alder thickets near sea level around upper Cook Inlet that hosts representatives of two subspecies-groups of the Fox Sparrow. Passerella i. zaboria prefers the mixed boreal forest (e.g., D, and background in rest), whereas $P$. i. sinuosa prefers alder thickets (e.g., C, and foreground in rest).

Photos by Laura McDuffie

\section{Vocal Variation}

The songs of sinuosa and zaboria differ notably in pattern, cadence, and variability. I have not assessed vocal variation between these two taxa comprehensively, but many of the specimens have archived linked audio recordings (Table 1), and here I interpret their songs' differences roughly. The songs of zaboria were generally very consistent, both from individual to individual and within a single individual's repertoire, to the extent that around upper Cook Inlet this subspecies appeared to sing a single song type. The songs of zaboria were more drawn out, languid, and had more pure-toned upswept notes than did the songs of sinuosa (Figure 5). In comparison, the songs of sinuosa were much choppier, less lyrical, and varied more, within a single individual's repertoire as well as from bird to bird. Many examples of sinuosa gave multiple notes between songs, a pattern that was generally absent in zaboria. Many examples of sinuosa sang songs of two alternating types. One song type included a terminal series of repeated notes that was absent in songs of zaboria (Figure 5). Most individual Fox Sparrows were identifiable to subspecies in the field by their song. More research on this subject is needed to quantify the amount of individual variation and degree of overlap (if any) in songs between these subspecies.

I recorded the songs of three individuals that I later identified as intergrades from specimens (Table 1). One of these (UAM 34098) sang a relatively 


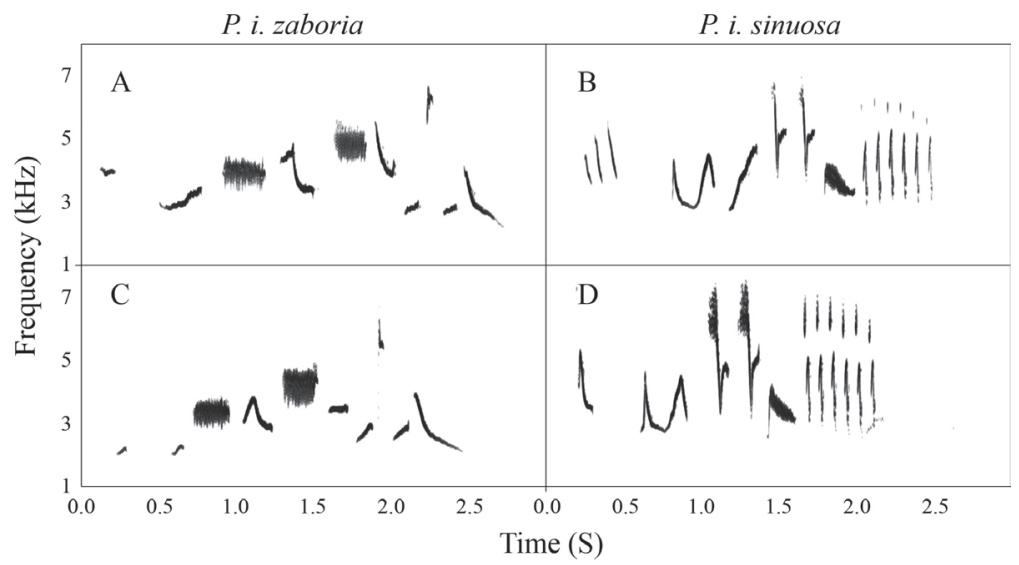

FIGURE 5. Songs of the two subspecies of the Fox Sparrow breeding around Anchorage, from recordings archived at the Macaulay Library (ML), Cornell Lab of Ornithology. Left column, zaboria, right column, sinuosa. Note the repeated notes at the end of the songs of sinuosa, repetitions that are missing entirely from songs of zaboria. These selected songs represent the extremes in differences; this topic requires additional investigation. (A), UAM 34095 and ML 118767; (B), UAM 34101 and ML 118751; (C), UAM 34096 and ML 118748; (D), UAM 38225 and ML 516992.

typical sinuosa song, another (UAM 40402) sang a relatively typical zaboria song, and the last (UAM 38229) sang a song that was intermediate but more similar to that of zaboria. This assessment should be taken with care, as characterizing the vocalizations in this area of contact was not my focus, and more work is needed for a thorough understanding of the vocal variation between these two subspecies-groups in areas of contact.

\section{DISCUSSION}

This is the first detailed published account of breeding contact between Passerella iliaca zaboria and sinuosa, representatives of the iliaca and unalaschcensis subspecies-groups of the Fox Sparrow. From my observations, specimens, and recordings, it is clear that near Anchorage these taxa do not meet in a homogeneous intergradation zone of phenotypically similar but intermediate individuals. The fact that in a discrete zone of contact, parental and intermediate phenotypes occur together, rather than a broad cline of intermediate individuals, suggests that evolutionary pressure is restricting free interbreeding or reducing the fitness of intergrades. There are many mechanisms that could result in this pattern, from pre-zygotic mechanisms such as positive assortative mating to post-zygotic mechanisms such as negative selection of intergrades. Another explanation is that contact between these subspecies is so recent that despite free interbreeding a continuous phenotypic gradient has not yet been established. It is unknown how long sinuosa and zaboria Fox Sparrows have been in contact in upper Cook Inlet. However, on the basis of specimens at UAM collected by Leonard Peyton in 
1969, who was the first ornithologist to make note of this contact area, and the brief description in Williamson and Peyton (1962), it is apparent that these subspecies were in contact by the early 1960s and likely much earlier. Furthermore, it is difficult to exclude the possible influence of anthropogenic habitat changes that may have facilitated the recent contact of these two taxa, as Hunn and Baudette (2014) showed for subspecies of the White-crowned Sparrow (Zonotrichia leucophrys). However, in both mature lowland boreal forest and mid-montane transitional forest, I observed both zaboria and sinuosa in what appeared to be natural habitats unaltered by anthropogenic factors. With that said, sinuosa also took advantage of recent regrowth of alders in disturbed areas (e.g., overgrown gravel pits), particularly in the lowland area. I refrain from suggesting that these results provide support for recognizing these two subspecies groups as independent species. My observations lack a genetic assessment for such a conclusion and come from a single small point of contact that should not be used as a proxy for a comprehensive understanding of the interactions between these two subspecies-groups in all areas of their contact.

The pattern I observed of sympatry of zaboria and sinuosa with limited intergradation around upper Cook Inlet stands in contrast to the situation of other species whose coastal and interior forms come into contact in the same region. The best comparable example is of the Orange-crowned Warbler (Leiothlypis celata), of which the interior subspecies celata and coastal lutescens intergrade from the Kenai Peninsula through at least upper Cook Inlet (Gilbert and West 2015). Unlike those of the Fox Sparrow, these two warbler subspecies form a broad cline of intermediate populations. In the Anchorage area (pers. obs.) and the Kenai Peninsula (Gilbert and West 2015; UAM specimens) populations are relatively homogeneous and phenotypically intermediate (i.e., both parental phenotypes do not occur in sympatry).

There are many avenues for more research on this contact area between these two groups of Fox Sparrow subspecies. First, the spatial limits of this contact area need to be identified. Sampling to the north into the Alaska Range in the Susitna River drainage and to the northeast into the Talkeetna Mountains along the Matanuska River drainage would identify the northern (interior) extent of the influence of coastal sinuosa. Similarly, sampling to the south along Turnagain Arm and into the Kenai Peninsula would define the southern (coastal) limit of the influence of zaboria. Studies that address the degree of assortative mating between these two subspecies groups would provide information essential to our understanding of this situation. Furthermore, this contact area might lend itself well to genomic research on factors that limit intergradation between these forms or regions of the genome linked to differences in plumage or migration routes. I hope that future researchers can build on these observations and begin to answer some of the more interesting evolutionary questions that can be asked through the Fox Sparrow.

\section{ACKNOWLEDGMENTS}

I am indebted to Dan Gibson for providing constructive input throughout my study and for encouraging me to write this information up for publication. I thank Jack Withrow (UAM) for curating the series of specimens, for providing an inde- 
pendent assessment of specimen identification, and for loaning specimens to the University of Kansas for my examination. Dan Ruthrauff, Kimball Garrett, Robert Zink, and Bryce Robinson all provided constructive reviews of this manuscript; I appreciate their input. Copy edits and additional input provided by Philip Unitt improved the manuscript. Kevin Winker and Jack Withrow allowed me to collect museum specimens under the UAM's state and federal collecting permits, and Kristie Craig authorized access to military land not open to the public. I thank Laura McDuffie for taking habitat photos on request and Theodore Tobish for discussion and sharing his expertise on the birds of upper Cook Inlet. Last, I thank Jim Johnson for his professional support of my efforts that have resulted in this publication and Wendy Holman for her continuing support.

\section{LITERATURE CITED}

Baldassarre, D. T., White, T. A., Karubian, J., and Webster, M. S. 2014. Genomic and morphological analysis of a semipermeable avian hybrid zone suggests asymmetrical introgression of a sexual signal. Evolution 68:2644-2657; doi. org/10.1111/evo.12457.

Billerman, S. M., Cicero, C., Bowie, R. C. K., and Carling, M. D. 2019. Phenotypic and genetic introgression across a moving woodpecker hybrid zone. Molec. Ecol. 28:1692-1708; doi.org/10.1111/mec.15043.

Delaney, K. S., Zafar, S., and Wayne, R. K. 2008. Genetic divergence and differentiation within the Western Scrub-Jay (Aphelocoma californica). Auk 125:839-849; doi.org/10.1525/auk.2008.07088.

Dixon, K. L. 1989. Contact zones of avian congeners on the southern Great Plains. Condor 91:15-22; doi.org/10.2307/1368143.

Gibson, D. D., and Withrow, J. J. 2015. Inventory of the species and subspecies of Alaska birds, second edition. W. Birds 46:94-185.

Gilbert, W. M., and West, G. C. 2015. Morphological expression in putative intergrades between two subspecies of Orange-crowned Warbler (Oreothlypis celata) on the Kenai Peninsula, Alaska. Wilson J. Ornithol. 127:29-42; doi. org/10.1676/13-153.1.

Gill, F., Donsker, D., and Rasmussen, P. 2020. IOC world bird list, version 10.1; www. worldbirdnames.org.

Harrison, R. G. (ed.) 1993. Hybrid Zones and the Evolutionary Process. Oxford Univ. Press, New York.

Hunn, E. S., and Beaudette, D. 2014. Apparent sympatry of two subspecies of the White-crowned Sparrow, Zonotrichia leucophrys pugetensis and gambelii, in Washington state. W. Birds 45:132-140.

Irwin, D. E., Milá, B., Toews, D. P. L., Brelsford, A., Kenyon, H. L., Porter, A. N., Grossen, C., Delmore, K. E., Alcaide, M., and Irwin, J. H. 2018. A comparison of genomic islands of differentiation across three young avian species pairs. Molec. Ecol. 27:4839-4855; doi.org/10.1111/mec.14858.

Jacobsen, F., and Omland, K. E. 2012. Extensive introgressive hybridization within the northern oriole group (genus Icterus) revealed by three-species isolation with migration analysis. Ecol. Evol. 2:2413-2429; doi.org/10.1002/ece3.365.

Manthey, J. D., and Robbins, M. B. 2016. Genomic insights into hybridization in a localized region of sympatry between pewee sister species (Contopus sordidulus $\times$ C. virens) and their chromosomal patterns of differentiation. Avian Res. 7:1-8; doi.org/10.1186/s40657-016-0040-7.

Mettler, R. D., and Spellman, G. M. 2009. A hybrid zone revisited: Molecular and morphological analysis of the maintenance, movement, and evolution of a Great Plains avian (Cardinalidae: Pheucticus) hybrid zone. Molec. Ecol. 18:3256-3267; doi.org/10.1111/j.1365-294X.2009.04217.x. 
Oswald, J. A., Harvey, M. G., Remsen, R. C., Foxworth, D. U., Dittmann, D. L., Cardiff, S. W., and Brumfield, R. T. 2019. Evolutionary dynamics of hybridization and introgression following the recent colonization of Glossy Ibis (Aves: Plegadis falcinellus) into the New World. Molec. Ecol. 28:1675-1691; doi.org/10.1111/ mec. 15008 .

Rising, J. D. 1970. Morphological variation and evolution in some North American orioles. Syst. Zool. 19:315-351; doi.org/10.2307/2412275.

Rising, J. D. 1983. Great Plains hybrid zones. Current Ornithol. 1:131-157; doi. org/10.1007/978-1-4615-6781-3_5.

Short, L. L. 1965. Hybridization of the flickers (Colaptes) of North America. Bull. Am. Mus. Nat. Hist. 129:307-428.

Sibley, C. G., and Short, L. L. 1964. Hybridization in the orioles of the Great Plains. Condor 66:130-150; doi.org/10.2307/1365391.

Swarth, H. S. 1920. Revision of the avian genus Passerella with special reference to the distribution and migration of the races in California. Univ. Calif. Publ. Zool. 21:75-224.

Toews, D. P. L., Taylor, S. A., Vallender, R., Brelsford, A., Butcher, B. G., Messer, P. W., and Lovette, I. J. 2016. Plumage genes and little else distinguish the genomes of hybridizing warblers. Current Biol. 26:2313-2318; doi.org/10.1016/j. cub.2016.06.034.

Williamson, F. S. L., and Peyton, L. J. 1962. Faunal relationships of birds in the Iliamna Lake area, Alaska. Biol. Papers Univ. Alaska 5.

Walsh, J., Billerman, S. M., Rohwer, V. G., Butcher B. G., and Lovette, I. J. 2020. Genomic and plumage variation across the controversial Baltimore and Bullock's oriole hybrid zone. Auk 137:1-15; doi.org/10.1093/auk/ukaa044.

Zink, R. M. 1994. The geography of mitochondrial DNA variation, population structure, hybridization, and species limits in the Fox Sparrow (Passerella iliaca). Evolution 48:96-111; doi.org/10.1111/j.1558-5646.1994.tb01297.x.

Zink, R. M., and Weckstein, J. D. 2003. Recent evolutionary history of the Fox Sparrows (genus: Passerella). Auk 120:522-527; doi.org/10.1642/00048038(2003)120[0522:REHOTF]2.0.CO;2.

Accepted 5 January 2021 